\title{
SISTEM INFORMASI MONITORING ANTRIAN DAN REKOMENDASI DOKTER KANDUNGAN BERBASIS MOBILE
}

\section{Mobile Based Queue Monitoring Information System and Gynecologist Recommendations}

\author{
Fadli Fairuz Ramadhan, fadli.personal@gmail.com ${ }^{1)}$, Yunita Sartika Sari, \\ yunita.sartikaa@gmail.com ${ }^{2}$ \\ ${ }^{1)}$ Teknik Informatika, Fakultas Teknologi dan Desain, Universitas Bunda Mulia \\ ${ }^{2)}$ Program Studi Sistem Informasi, Universitas Mercu Buana
}

\begin{abstract}
The health of pregnant women cannot be separated from the role of obstetricians. Obstetricians in charge of examining and monitoring fetal development in the womb as well as the health of pregnant women. To get maximum service, the best obstetrician is needed. The selection of obstetricians at this time is done by surveying obstetricians around the place of residence or by gathering information from other people, either by asking the person directly or through forums on the internet. The waiting time for unproductive services is also a problem for pregnant women in seeing a gynecologist because it takes a long time. Queue information that is difficult to obtain and inaccurate makes pregnant women and their companions have to really monitor the queue even though the waiting time can be used for other more useful activities. For this reason, this research will build a mobile-based obstetric monitoring and queuing information system for mobile doctors to make it easier for pregnant women to check with obstetricians. In this study, the highest rating given by patients later as an assessment of obstetrician's recommendations. The results of this study are in the form of a queue monitoring information system and obstetrician rating based on the largest preference value.
\end{abstract}

Keywords: monitoring, recommendations, mobile, queue

\begin{abstract}
ABSTRAK
Kesehatan ibu hamil tidak lepas dari peran dokter kandungan. Dokter kandungan bertugas melakukan pemeriksaan dan monitoring perkembangan janin didalam kandungan sekaligus kesehatan ibu hamil. Untuk mendapatkan pelayanan maksimal, dibutuhkan dokter kandungan yang terbaik. Pemilihan dokter kandungan pada saat ini dilakukan dengan cara survei dokter kandungan yang ada di sekitar tempat tinggal atau dengan mengumpulkan informasi dari orang lain, baik dengan cara menanyakan langsung kepada orang tersebut atau lewat forum yang ada di internet. Waktu tunggu pelayanan yang tidak produktif juga merupakan masalah bagi ibu hamil dalam memeriksa ke dokter kandungan karena memakan waktu yang lama. Informasi antrian yang sulit didapat dan tidak akurat membuat ibu hamil dan pendamping harus benar-benar memonitor antrian padahal waktu menunggu tersebut dapat dimanfaatkan untuk kegiatan lain yang lebih bermanfaat. Untuk itu, penelitian ini akan membangun sebuah system informasi monitoring antrian dan rating dokter kandungan berbasis mobile untuk memudahkan ibu hamil dalam memeriksa ke dokter kandungan. Pada penelitian ini, rating tertinggi yang diberikan oleh pasien nantinya sebagai penilaian rekomendasi dokter kandungan. Hasil dari penelitian ini adalah berupa system informasi monitoring antrian dan rating dokter kandungan berdasarkan nilai preferensi terbesar.
\end{abstract}

Keywords: monitoring, recommendations, mobile, antrian 


\section{PENDAHULUAN}

Kesehatan ibu hamil tidak lepas dari peran dokter kandungan. Dokter kandungan merupakan orang yang bertugas untuk membantu ibu hamil dari awal kehamilan sampai melahirkan. Dokter kandungan akan melakukan pemeriksaan dan monitoring perkembangan janin di dalam kandungan sekaligus kesehatan ibu hamil. Pemeriksaan kehamilan juga sangat penting untuk mendiagnosis risiko kelainan atau penyakit.

Untuk mendapatkan pelayanan maksimal dibutuhkan dokter kandungan yang terbaik. Pemilihan dokter kandungan pada saat ini dilakukan dengan cara survei bidan atau dokter kandungan yang ada di sekitar tempat tinggal atau dengan mengumpulkan informasi dari orang lain, baik dengan cara menanyakan langsung kepada orang tersebut atau lewat forum yang ada di internet. Pemilihan dokter kandungan memiliki beberapa pertimbangan seperti jenis kelamin dokter kandungan yang akan dipilih, jarak dari tempat tinggal dengan tempat dokter praktek, tarif konsultasi, tarif melahirkan, popularitas dokter, pengalaman dokter dan rekomendasi dari orang-orang terdekat atau terpecaya. Dalam pemilihan dokter kandungan kebutuhan setiap pasien berbeda-beda sehingga mempengaruhi setiap dokter kandungan yang sudah pernah dikunjungi atau yang akan dikunjungi.

Waktu tunggu pelayanan yang tidak produktif juga merupakan masalah bagi ibu hamil dalam memeriksa ke dokter kandungan karena memakan waktu yang lama, karena informasi antrian yang sulit didapat dan tidak akurat membuat ibu hamil dan pendamping harus benar-benar memonitor antrian padahal waktu menunggu tersebut dapat dimanfaatkan untuk kegiatan lain yang lebih bermanfaat.

Hal ini menjadi salah satu dasar dalam pembuatan sistem informasi monitoring dan rating dokter kandungan sesuai dengan keinginan dan kebutuhan pasien serta memudahkan pasien untuk mendapatkan rekomendasi dokter kandungan.
Penelitian ini juga bertujuan menjadi aplikasi yang membantu ibu hamil dalam memaksimalkan proses pelayanan kesehatan dengan menyediakan layanan monitoring antrian agar ibu hamil tidak perlu menghabiskan waktu hanya untuk menunggu, yang dimana waktu menunggu itu bisa ibu hamil gunakan untuk kegiatan lain yang lebih menyenangkan.

\section{TINJAUAN PUSTAKA}

Sistem Pendukung Keputusan (SPK) adalah suatu sistem yang dikendalikan oleh satu atau lebih pengambil keputusan yang dapat memabantu kegiatan pembuatan keputusan dengan menyediakan sekumpulan tools yang terorganisasi yang dimaksudkan untuk meningkatkan efektifitas hasil keputusan[1].

SPK digunakan untuk menyelesaikan masalah semi dan tidak tersetruktur. SPK dibuat untuk membantu pengambil keputusan, dan bukan menggantikan mereka.

Suatu SPK memiliki empat subsistem utama yang menentukan kapabilitas teknis SPK tersebut, yaitu subsistem manajemen data, subsistem manajemen model, subsistem mesin pengetahuan (knowledge engine), dan subsistem antarmuka. Penjelasan untuk setia komponen disajikan sebagai berikut.

\section{Subsistem manajemen data}

Komponen ini mengambil, menyimpan, dan mengorganisasi data yang relevan untuk suatu masalah pengambilan keputusan.

\section{Sub sistem manajemen model}

Peran dari subsistem ini adalah melakukan pengambilan, penyimpanan, dan pengorganisasian kegiatan yang berhubungan dengan model kuantitatif yang menyediakan kemampuan analitis untuk SPK.

\section{Sub sistem mesin pengetahuan}

Mesin pengetahuan merupakan inti dari SPK. Data dan model secara bersama-sama digunakan untuk menghasilkan aplikasi 
yang membantu pengguna dalam mengambil keputusan.

\section{Sub sistem antar muka}

Antar muka merupakan alat komunikasi antara pengguna dan sistem. Data, model, dan komponen komponen pemrosesan akan mudah diakses dan dimanipulasi jika terdapat antarmuka yang mudah dimengerti oleh pengguna.

Secara umum Sistem Pendukung Keputusan dibangun oleh tiga komponen besar yaitu database Management, Model Base dan Software System/User Interface[2]. Komponen SPK tersebut dapat digambarkan seperti gambar 1.

Database Management merupakan subsistem data yang terorganisasi dalam suatu basis data. Data yang merupakan suatu sistem pendukung keputusan dapat berasal dari luar maupun dalam lingkungan. Untuk keperluan SPK, diperlukan data yang relevan dengan permasalahan yang hendak dipecahkan melalui simulasi.

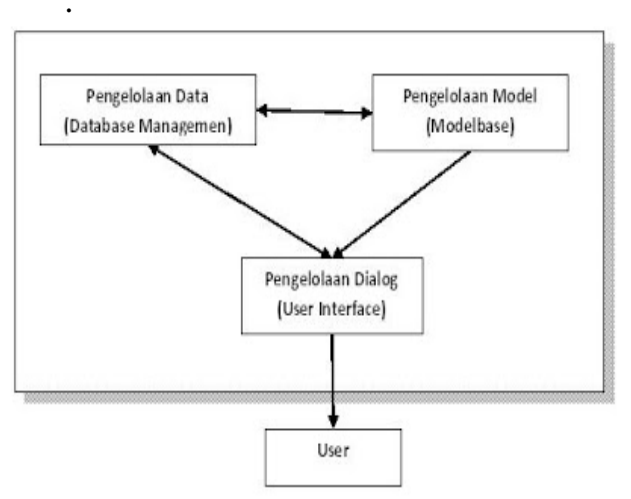

Gambar 1 Komponen Sistem Penunjang Keputusan

\footnotetext{
model $\begin{gathered}\text { Model Base merupakan suatu } \\ \text { yang }\end{gathered}$ merepresentasikan permasalahan kedalam format kuantitatif (model matematika sebagai contohnya) sebagai dasar simulasi atau pengambilan keputusan, termasuk didalamnya tujuan dari permaslahan (objektif), komponenkomponen terkait, batasan-batasan yang ada (constraints), dan hal-hal terkait lainnya. Model Base memungkinkan pengambil keputusan menganalisa secara utuh dengan
}

mengembangkan dan membandingkan solusi alternatif.

User Interfase / Pengelolaan Dialog terkadang disebut sebagai subsistem dialog, merupakan penggabungan antara dua komponen sebelumnya yaitu Database Management dan Model Base yang disatukan dalam komponen ketiga (user interface), setelah sebelumnya dipresentasikan dalam bentuk model yang dimengerti computer. User Interface menampilkan keluaran sistem bagi pemakai dan menerima masukan dari pemakai kedalam Sistem Pendukung Keputusan.

SPK dapat memberikan berbagai manfaat dan keuntungan. Manfaat yang dapat diambil dari SPK adalah :

1) SPK memperluas kemampuan pengambil keputusan dalam memproses data / informasi bagi pemakainya.

2) SPK membantu pengambil keputusan untuk memecahkan masalah terutama barbagai masalah yang sangat kompleks dan tidak terstruktur.

3) SPK dapat menghasilkan solusi dengan lebih cepat serta hasilnya dapat diandalkan.

4) Walaupun suatu SPK mungkin saja tidak mampu memecahkan masalah yang dihadapi oleh pengambil keputusan, namun dia dapat menjadi stimulan bagi pengambil keputusan dalam memahami persoalannya,karena mampu menyajikan berbagai alternatif pemecahan.

Estimasi, dalam arti umum merupakan usaha untuk menilai atau memperkirakan suatunilai melalui analisis perhitungan dan berlandaskan pada pengalaman.Menurut Smith, estimasi adalah suatu proses untuk memperkiraka jumlah, waktu, atau kejadian yang akan terjadi di masa depan, dimana semakin banyak ketidakpastian yang ada akan menyebabkan proses tersebut semakin rumit dan komplek. Tujuan estimasi melakukan adalah untuk mendapatkan perkiraan yang paling mendekati kejadian sebenarnya yang akan berlangsung, dengan 
mepertimbangkan

kemungkinan yang ada.

kemungkinan-

\section{Penelitian Terkait}

Penelitian Nureni Firdianti pada

tahun 2017 dengan judul "Sistem

Pendukung Keputusan Pemilihan Dokter Kandungan Menggunakan TOPSIS". Pada penelitiannya, data yang digunakan merupakan pengalaman dokter kandungan berdasarkan usia, tarif konsultasi, tarif melahirkan, popularitas dokter kandungan berdasarkan jumlah pasien, dan posisi yang ditempuh dari tempat tinggal ke tempat dokter kandungan. Hasil dari penelitian ini dengan menggunakan metode TOPSIS adalah berupa rekomendasi dokter kandungan berdasarkan nilai preferensi terbesar. pengujian sistem dilakukan terhadap 10 user dengan nilai bobot setiap usernya berbeda. Sistem diuji berdasarkan nilai kesesuaian perangkinan hasil sistem dengan hasil data sebenarnya. Hasil dari kesesuaian pengujian antara hasil sistem dengan hasil data sebenarnya menghasilkan $40 \%$ perbedaan. Sehingga sistem yang dibuat memiliki akurasi kesalahan yang besar dan tidak tepat[3].

Penelitian Maelani Hodia pada tahun 2017 dengan judul "Perancangan Sistem Informasi Praktek Klinik Kebinanan pada Stikes Qamarul Huda". Perancangan Sistem Informasi Praktek Klinik Kebidanan (PKK) pada STIKes Qamarul Huda menggunakan metode perancangan Unified Modeling Language (UML) yang terdiri dari perancangan Use Case Diagram, Activity Diagram, Perancangan Tabel, Relasi Tabel, Struktur Menu dan Interface (antar muka pengguna sistem), metode pengumpulan data menggunkan metode observasi, wawancara dan studi pustaka. Perancangan sistem informasi praktek kebidanan akan menghasilkan sebuah sistem yang dapat mempermudah kegiatan operasional praktek klinik kebidanan, mulai dari pendaftran lokasi praktek, pemilihan dosen pembimbing, pengolahan dosen pembimbing, penempatan lokasi praktek klinik kebidanan dan pembimbingan[4].

Penelitian lainnya tentang Sistem Pendukung Keputusan untuk meningkatkan Kualitas Pelayanan di Bidang Kesehatan dilakukan oleh Anny Kartika Sari pada tahun 2016. Penelitian ini mencoba mengatasi kesulitan yang dihadapi para manajer atau pimpinan instansi dalam permasalahan yang berkaitandengan pengukuran kualitas produk pelayanannya. Bidang pelayanan yang menjadi pokok penelitian adalah kesehatan. Sistem pendukung keputusan yang dibuat dapat digunakan untuk menentukan dimensi pelayanan yang kualitasnya paling lemah. Sistem pendukung keputusan yang dibangun berbasis web. Dimensi pelayanan yang relevan dengan bidang kesehatan ditinjau dari data yang didapatkan melalui kuesioner. Metode yang dipakai dalam peninjauan tersebut adalah metode SERVQUAL. Selanjutnya, optimisasi diterapkan untuk memaksimumkan kualitas dimensi pelayanan yang lemah sesuai dengan atribut atribut untuk dimensi pelayanan yang bersangkutan. Karena atribut atribut pada masing-masing dimensi merupakan parameter yang tidak tentu, maka perumusan optimisasi fuzzy akan lebih efektif. Optimisasi fuzzy dengan pendekatan fungsi ketidakpuasan diselesaikan dengan algoritma genetika[5].

\section{METODOLOGI DAN RANCANGAN PENELITIAN}

\section{Metode Pengumpulan Data}

Pengumpulan data dilakukan untuk memperoleh informasi yang dibutuhkan dalam rangka mencapai tujuan penelitian. Tujuan yang diungkapkan dalam bentuk hipotesis merupakan jawaban sementara terhadap pertanyaan penelitian.metode pengumpulan data bisa dilakukan dengan cara:

a. Wawancara

Wawancara adalah suatu bentuk komunikasi verbal jadi semacam percakapan yang bertujuan memperoleh informasi[6]. Orang yang diwawancari pada penelitian ini adalah pasien ibu hamil dan dokter kandungan.

b. Kuesioner

Merupakan suatu teknik pengumpulan data secara tidak langsung (peneliti tidak langsung bertanya jawab dengan responden). Instrumen atau alat pengumpulan datanya juga disebut 
angket berisi sejumlah pertanyaanpertanyaan yang harus dijawab atau direspon oleh responden. Responden mempunyai kebiasaan untuk memberikan jawaban atau respon sesuai dengan presepsinya. Pertanyaanpertanyaan dari kuisioner ini nantinya akan dijadikan sebagai acuan dalam menentukan kebutuhan fungsional dan non fungsional system[7].

c. Observasi

Metode pengumpulan data dengan melakukan pengamatan dan pencatatan secara teliti dan sistematis atas gejala gejala (fenomena) yang sedang diteliti. Pada kegiatan observasi ini dilakukan dengan mengumpulkan data melalui pengamatan langsung terhadap fenomena-fenomena yang terjadi dilokasi penelitian[8].

\section{Instrumentasi}

Dalam penelitian ini instrumen yang dilakukan dalam pengumpulan data antara lain:

a. Wawancara, instrumen yang digunakan berupa daftar wawancara.

b. Kuesioner/angket, instrumen yang digunakan berupa butiran-butiran pertanyaan.

c. Observasi, instrumen yang digunakan adalah penelitian yang melakukan pengamatan objek penelitian.

\section{Teknik Analisis Data}

Teknik analisis data merupakan cara menganalisis data penelitian untuk menjawab permasalahan yang ada. Teknik analisis data dalam penelitian ini menggunakan dukungan data observasi, wawancara, dan kuesioner.

Tahap analisis dan desain dengan pendekatan berorientasi objek dengan UML, sedangkan desain sistem meliputi perancangan database.

\section{HASIL PENELITIAN \\ Alur Proses Bisnis}

Langkah pertama dalam percobaan ini adalah menyiapkan perangkat keras seperti, Perancangan system bertujuan untuk memberi gambaran fitur system dan kerja system guna mencapai tujuan aplikasi. Beberapa alur proses utama dari system dijelaskan sebagai berikut:

a. Alur Proses Pendaftaran Pelayanan

Alur proses perndaftaran pelayanan menjelaskan saat pasien mendaftar untuk pemerikasaan atau pelayanan kesehatan lainnya. Pasien diminta untuk memilih dokter yang sedang tersedia pada sesi tersebut, setelag memilih pasien akan mendapatkan nomor antrian sesuai dokter yang dipilih dan diarahkan ke form antrian.

b. Alur Proses Pelayanan Dokter

Alur proses pelayanan dokter menjelaskan awal pasien akan mendapatkan pelayanannya. Dimulai dari dokter membuka pelayanan jika nomor antrian pasien sama dengan nomor antrian berjalan, maka akan ada notifikasi di aplikasi pasien dan pasien diberi waktu 1 menit untuk segera keruang pemeriksaan jika lebih dari 1 menit belum sampai makan nomor antrian akan dilanjutkan dan pasien akan menunggu 1 antrian pasien baru kemudian akan dipanggil kembali. Setelah pasein sampai diruang maka dokter menginfokan kepada system bahwa dokter sedang melakukan pelayanan dan system akan menyipan waktu mulai pelayanan.

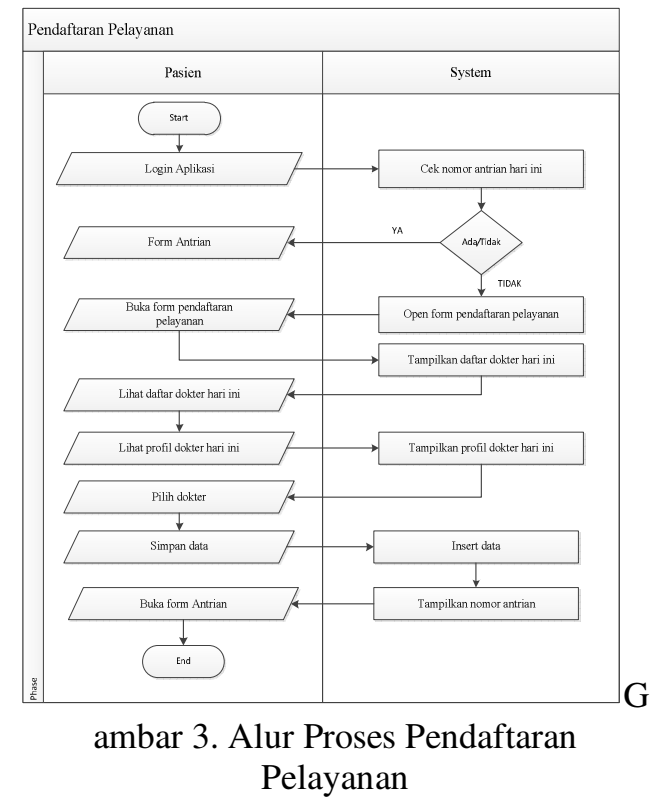


Setelah pelayanan selesai dokter menginfokan kepada system bahwa dokter telah selesai melakukan pelayanan dan system akan menyipan waktu selesai pelayanan. Waktu mulai dan waktu selesai pelayanan akan mengkalkulasi yang akan disimpan sebagai rata-rata waktu pelayanan dokter tersebut. Setelah pelayanan pasien akan diarahkan menuju alur proses rating.

c. Alur Proses Rating Dokter

Setelah pelayanan pasien akan diarahkan menuju alur proses rating. Pada proses ini pasien diberi saranan untuk memberi penilaian terhadap pelayanan dokter menggunakan metode rating. Selain rating pasien juga diminta untuk memberikan alasan atas rating tersebut.

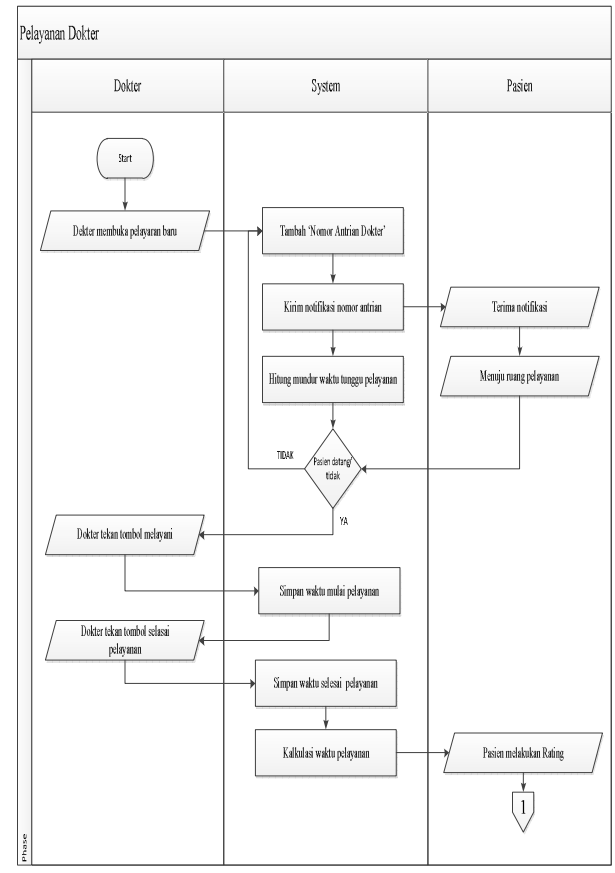

Gambar 4. Alur Proses Pelayanan Dokter

Gambar 6 merupakan use case diagram system antrian dan monitoring, terdapat 2 aktor yaitu admin dan pasien. Admin dapat mengelola data pasien, mengelola data dokter, mem-validasi pendaftaran, mengatur nomor antrian yang akan dilihat oleh pasien, dan mengelola rating yang diberikan oleh pasien.

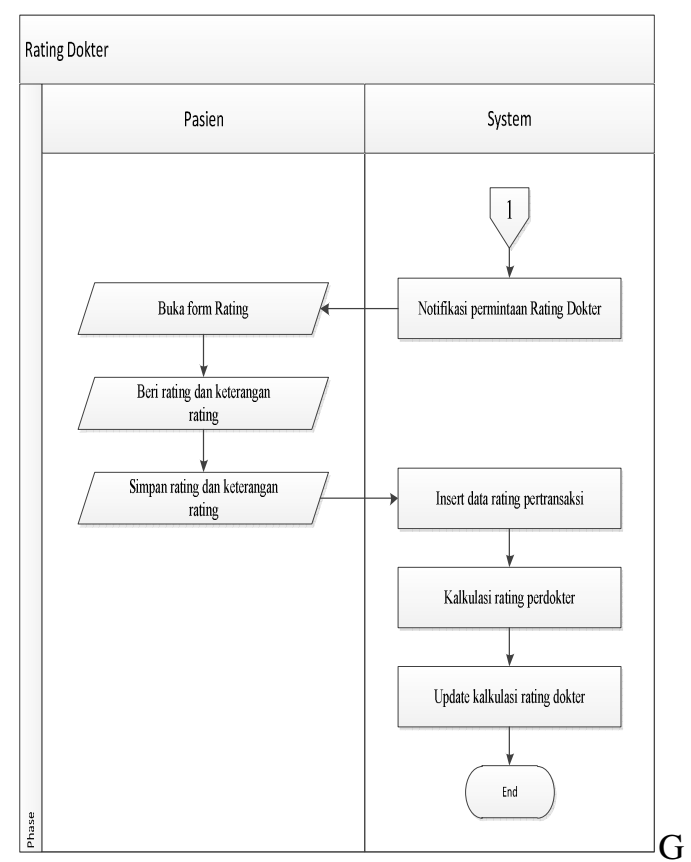

ambar 5. Alur Proses Rating Dokter

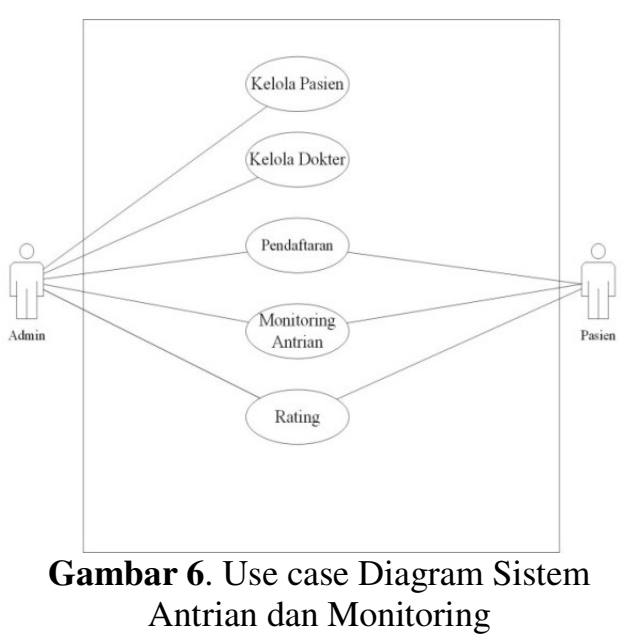

Gambar 7 menjelaskan alur kerja sistem saat pasien mendaftar antrian. Setelah pasien membuka aplikasi (menu daftar), pasien diminta untuk memilih jenis pembayaran dimana jenis pembayaran ini menentukan daftar dokter yang dapat melayaninya, tentunya yang masuk pada hari itu.

Pasien akan memilih dokter pada daftar dokter, pasien akan melihat profil dokter terlebih dahulu sebelum mengambil nomor antrian pada sistem. 
Jika pasien memutuskan untuk dilayani oleh dokter pilihannya maka pasien akan mendapat nomor antian dokter tersebut dan nama pasien akan masuk ke daftar pasien dokter terpilih.

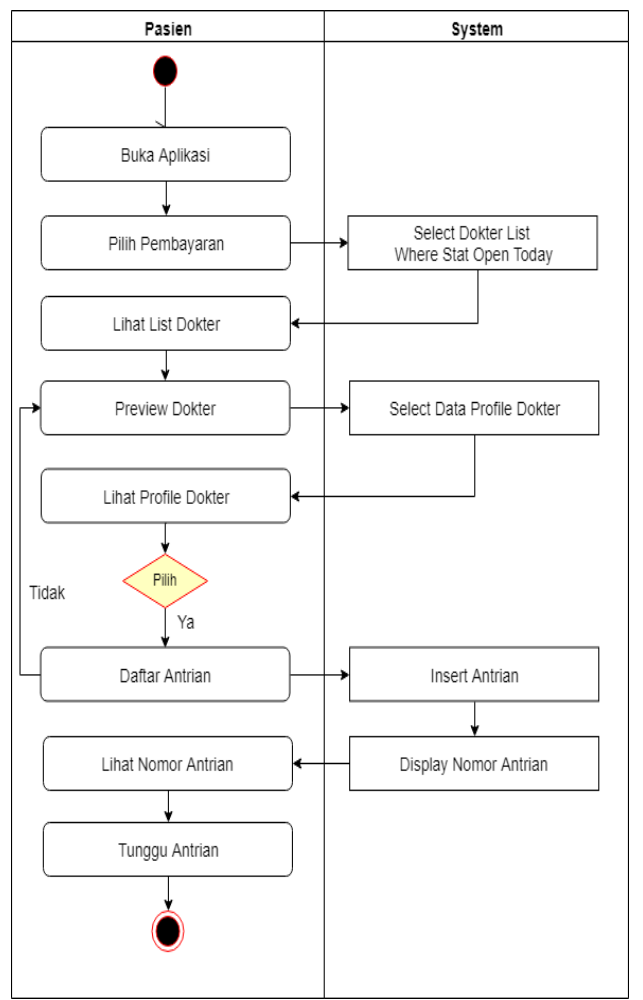

\section{Gambar 7. Flow Chart Diagram} Mendaftar Antrian

Gambar 8 menjelaskan alur kerja sistem saat pasien telah mendapat nomor antrian.

Sistem akan secara berulang dengan jeda waktu tertentu untuk mengecek berapa nomor antrian lagi sebelum pasien terlayani dan mengestimasi waktu tunggu pasien hingga terlayani.

Gambar 9 menjelaskan alur kerja sistem saat antran telah sampai pada nomor antrian pasien.

Sistem akan mengirimkan notifikasi pada aplikasi pasien bahwa nomor antrian telah sampai pada nomor pasien. Sistem memberikan waktu selama 60 detik untuk pasien merespon notifikasi tersebut, sebelum sistem akan melanjutkan nomor antrian jika pasien tidak merespon.

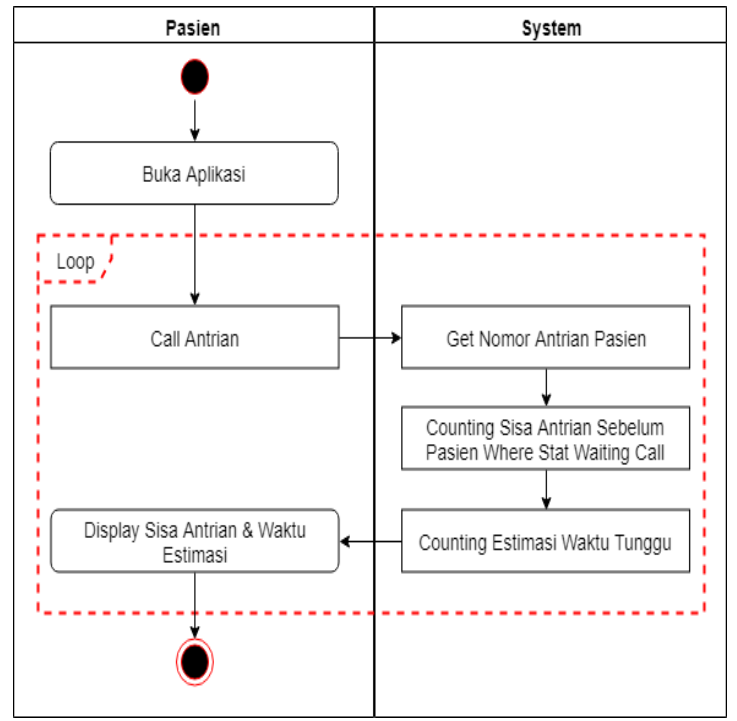

Gambar 8. Flow Chart Diagram Melihat Antrian

Jika pasien merespon notofikasi maka sistem akan berposisi menunggu pasien untuk sampai ke ruangan pelayanan selama 300 detik, jika dalam waktu 300 detik pasien tidak hadir di ruangan pelayanan maka sistem akan melanjutkan nomor antrian.

Jika pasien sampai ke ruangan pelayanan dalam waktu 300 detik maka sistem akan mulai menghitung waktu pelayanan dokter.

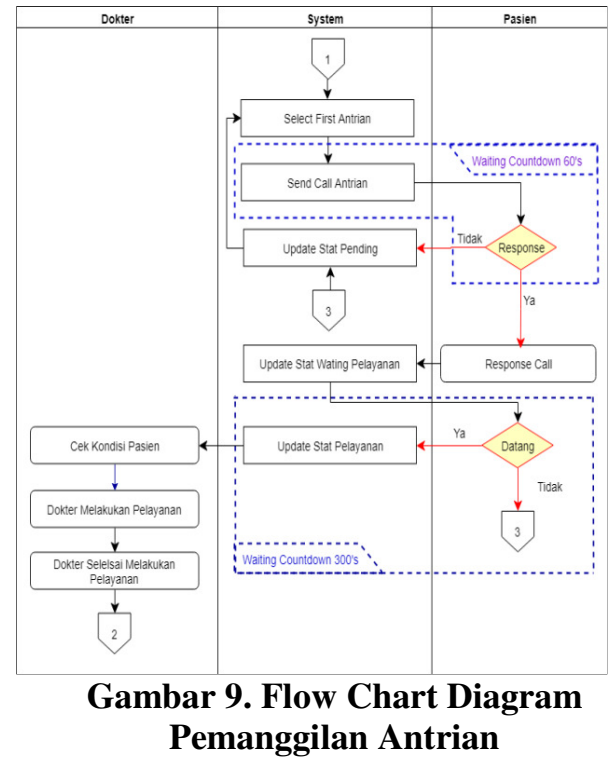




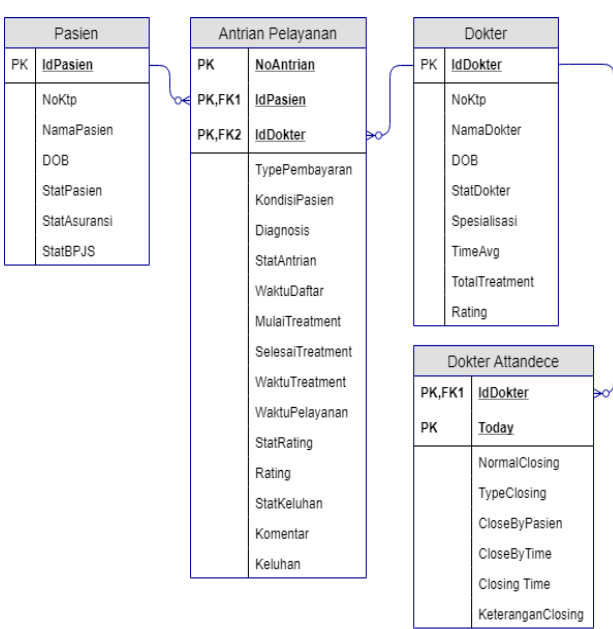

\section{Gambar 10. Rancangan Database}

\section{User Interface}

Gambar 11 menjelaskan bahwa aplikasi ini menawarkan 4 fitur utama, yaitu menu daftar, top ten dokter, my history, keluhan.

Menu daftar digunakan untuk pasien ambil nomor antrian, menu top ten dokter digunakan untuk pasien mendapat informasi sepuluh dokter terbaik dalam hal pelayanan.

Menu my history digunakan untuk pasien mengingat kapan saja pasien pernah memeriksakan kesehatannya dan menu keluhan digunakan untuk mendapatkan informasi daftar keluhan pasien.

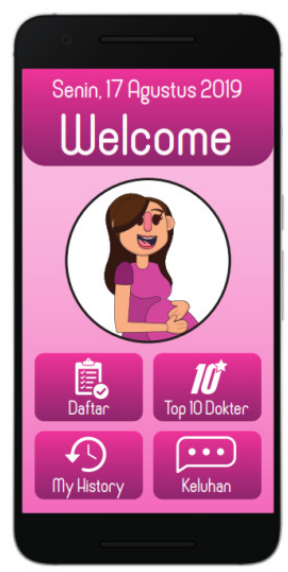

\section{Gambar 11. Tampilan Menu Utama}

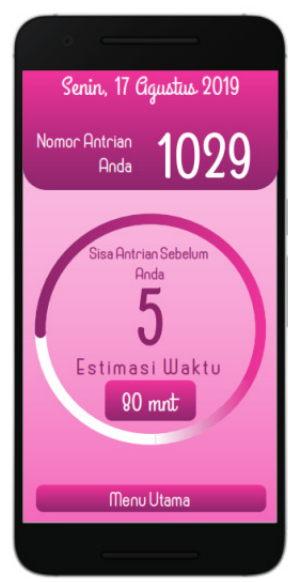

\section{Gambar 12. Tampilan Nomor Antrian}

Gambar 12 merupakan tampilan setelah pasien mendaftar pada antrian pelayanan yang berisikan informasi sisa antrian sebelum pasien yang belum terlayani dan estimasi waktu pasien terlayani.

Gambar 13 merupakan tampilan input rating, setelah pasien diminta untuk mengisi rating dan komentar atas pelayanan dokter tersebut, serta mengisi keluhan jika pasien merasa ada keluhan yang harus disampaikan untuk perbaikan pelayanan.

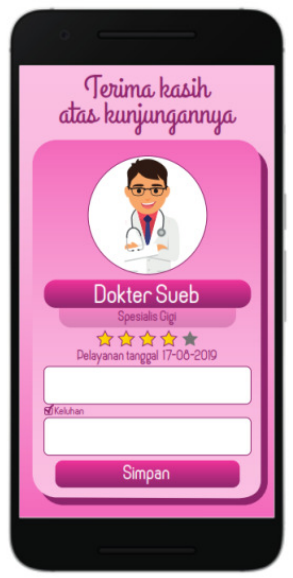

Gambar 13. Tampilan Komentar

\section{KESIMPULAN}

Aplikasi Sistem Informasi Monitoring dan Rekomendasi Dokter Kandungan Berbasis Mobile ini dapat 
memudahkan ibu hamil melakukan pemeriksaan kandungan.

Dengan dibuatnya Aplikasi Sistem

Informasi Monitoring dan Rekomendasi Dokter Kandungan Berbasis Mobile ini diharapkan dapat menurunkan waktu tunggu yang tidak efektif dalam melakukan pemeriksaan kandungan

Dengan adanya fitur rating pada aplikasi Sistem Informasi Monitoring dan Rekomendasi Dokter Kandungan Berbasis Mobile dapat memudahkan ibu hamil dalam memilih dokter kandungan yang diinginkannya.

Aplikasi ini dapat membantu memberikan informasi pada pemerintah sebagai bahan pertimbangan kinerja pelayanan rumah sakit dari aspek pelayanan dokter untuk pengembangan atau perbaikan pelayanan.

\section{DAFTAR PUSTAKA}

[1] O'Brien, James A., Marakas, George M, 2008,Management Informations System,Eighth Edition.New york : The McGraw-Hill Companies, Inc

[2] Pressman, S, Roger. Software Engineering: A Practitioner's Approach, 7th ed. Dialihbahasakan oleh Nugroho, Adi, et.al. Yogyakarta: ANDI, 2012.

[3] Firdianti, Nureni, Gunawan Abdillah, agus Komarudin : Sistem Pendukung Keputusan Pemilihan Dokter
Kandungan Menggunakan TOPSIS, Seminar Nasional Informatika dan Aplikasi, 2017

[4] Kartika Sari, Anny, Solikhatun, Erwin Sihombing : Sistem Pendukung Keputusan Untuk Meningkatkan Kualitas Pelayanan di Bidang Kesehatan, Seminar Nasional Matematika dan Pendidikan Matematika, 2016

[5] Hoodia, Maelani, Khairul Imtihan : Perancangan Sistem Informasi Praktek Klinik Kebidanan Stikes Qamarul Huda, Indonesian Jurnal on Networking and Security, 2017

[6] Noor, Juliansyah. 2014. Metodologi Penelitian. Jakarta: Kencana Prenada Media Group

[7] Sholikhah, Fatikhatus, Diema Hernyka Satyareni, Chandra Sukma : perancangan Sistem Pendukung Keputusan Pemilihan Pelanggan terbaik Menggunakan Metode Simple Additive Weighting (SAW) Pada Bravo Supermarket Jombang, Jurnal Ilmiah Teknologi Sistem Informasi,2016

[8] Dennis, Alan, at.al.,"Systems Analysis and Design with UML - 3rd Edition", John Wiley \& Sons, Inc, 2009 